\title{
Introduction: Ideology, Propaganda, and Political Discourse in the Xi Jinping Era
}

\author{
Ondřej Klimeš $^{1}$ (D) $\cdot$ Maurizio Marinelli ${ }^{2}$
}

Published online: 19 July 2018

(C) The Author(s) 2018

\begin{abstract}
The ideology, propaganda, and political discourse of the Communist Party of China (CPC) have continued to function as key elements of the political system of the People's Republic of China (PRC) in the post-Maoist period since 1978. In the first term of the Xi Jinping leadership (2012-2017), the CPC, for instance, elaborated on its guiding ideological concepts, devised inventive ideational framings of phenomena usually perceived as tangible (such as the "New Normal"), engaged in complex intellectual debates on crucial topics (such as "eco-civilization"), intensified and diversified its argumentation patterns and discursive strategies, and consolidated ideational governance over some citizens' individual values, beliefs, and loyalties. Furthermore, it is often no longer possible to differentiate between the CPC's internal and external propaganda, as seemingly exclusively domestic ideational and discursive issues increasingly correlate with international phenomena. However, the trends in the $\mathrm{Xi}$ era do not present paradigmatic shifts, but rather an overall reassertion-cuminnovation of previous Maoist and post-Maoist uses of ideology, propaganda, and political discourse, primarily aiming at strengthening one-party rule.
\end{abstract}

Keywords Communist Party of China $\cdot$ Xi Jinping $\cdot$ Ideology $\cdot$ Propaganda $\cdot$ Political discourse

Ondřej Klimeš

klimes@orient.cas.cz

$\triangle$ Maurizio Marinelli

M.Marinelli@sussex.ac.uk

1 Oriental Institute of the Czech Academy of Sciences, Prague, Czech Republic

2 University of Sussex, Brighton, UK 


\section{Introduction}

The idea behind this special issue derives from our intention to fill the void that exists in understanding the fundamentals of governance in today's China. The beginning of the new millennium has witnessed a resurgence of academic interest in how the Communist Party of China (CPC) has adapted its governance to new realities within the People's Republic of China (PRC) and its involvement in the globalization processes. This wave of studies has effectively led to a reconsideration of the former paradigm held by those China watchers who engaged in speculation about the prospect of China's democratization in response to the demise of communism in Central and Eastern Europe in the late 1980s. The current scholarly consensus holds that although the CPC has apparently vacated many policy sectors it previously monopolized, its internal reforms and ability to adapt to new realities have until now proved to be sufficient for the party to continue to manage the PRC as a Leninist partystate (e.g. $[4,11,19,20])$. It is the CPC's simultaneous ability to modernize and adapt, as well as its adherence to Leninist ideological and organizational principles, which has engendered a neo-socialist system where the combination of centralization, strengthening, and the adoption of a selective retreat of the party-state has played a crucial role in guaranteeing both economic growth and social stability ([15], 5-12). The state-centered paradigm, therefore, seems to remain the most valid one for the study of Chinese contemporary politics [6]. Since the ascendancy of the fifth generation's leadership in November 2012, the $\mathrm{CPC}$, with $\mathrm{Xi}$ Jinping at its core as the most powerful leader since Mao Zedong, has been intent on enhancing the party's governance over state and society and pursuing a proactive foreign policy [12].

The authors of the articles included in this special issue believe that official ideology, propaganda, and political discourse in contemporary China's political processes and everyday reality demand more scholarly attention. Before the 19th CPC Congress of 18-24 October 2017 brought increased international attention to the issue of ideology, few publications had discussed this phenomenon in the Xi era. In general, there has been a lack of systematic research on China's contemporary ideology, propaganda, and political discourse comparable to the seminal volumes dealing with the Maoist and early post-Maoist eras (e.g. [9, 16-18].

This collection of five articles, therefore, aims to partially fill this knowledge gap by presenting a multi-faceted investigation of the CPC's ideology, propaganda, and political discourse during the first term of Xi Jinping's leadership (2012-2017). A preliminary conversation on this topic was initiated at a workshop organized on 15 September 2015 by the Power and Strategies of Social and Political Order research platform of the Oriental Institute of the Czech Academy of Sciences (http://power. orient.cas.cz/), which also sparked a resolve among several of the participating presenters to continue their research and publish their conclusions in a collaborative format by the end of Xi Jinping's first five-year term. We were delighted that our publication proposal was accepted by the Journal of Chinese Political Science in the fall of 2015. Work-in-progress articles were presented as part of another workshop held in Prague on 15 June 2017, and were finalized and submitted for double-blinded peer review 
throughout the summer and fall of 2017, when an additional workshop was held in Prague on 27 October $2017 .{ }^{1}$

\section{Ideology, Propaganda, and Political Discourse in Contemporary China}

Before we started working on this project in 2015, scholars were in agreement that, despite the more pragmatic and rationalized policy agenda pursued by the CPC throughout the reform era in a new governing paradigm, ideology remained at the core of the PRC's political system. It serves as a belief system, which conveys a particular worldview and an outlook on an ideal society, and as the guide to the CPC's actions, which enables the party-state to legitimize and operationalize various practices, institutions, and organizations $[2,7,8]$. Propaganda is the "life blood" of the Chinese party-state as it remains one of the key means by which it secures popular support, which in turn is the source of the CPC's authority to govern in the post-revolutionary era $([1], 8)$. By means of propaganda, the party not only controls the dissemination of information and ideas, but also tailors its response to emerging socio-political challenges associated with modernization and globalization, thus preventing other actors from undermining the CPC's legitimacy and challenging its official narrative ([5], 4, 30). Through meticulously devised and controlled discursive practices, language use, and recourse to key vocabularies, the party-state aims to manage the complex ongoing transformations in China's politics, society, culture, and other realms [3, 13]. It can be argued that ideology, along with propaganda and political discourse, as well as efficient party-state organization, continue to hold together the PRC's "vast building made of different kinds of brick and stone" in much the same way as examined some fifty years ago by Franz Schurmann in his pioneering work Ideology and Organization in Communist China ([17], 1).

The following five articles explore some of the most significant developments in the ways in which official ideology, propaganda, and political discourse feature in contemporary China, providing a temporal focus on the first term of the Xi Jinping leadership (2012-2017). Due to our research and writing schedule, therefore, the conclusions of the respective articles do not reflect the outcomes of the 19th CPC Congress, even though they do so tangentially. Nevertheless, we believe that the Congress and its aftermath confirm our overall assertion of the lasting centrality of ideology and its operational implications for all actions taken by the CPC and, therefore, for all processes occurring in the PRC. This fact is more than openly evidenced by the coining of the expression "Xi Jinping Thought on Socialism with Chinese Characteristics for a New Era" (Xi Jinping xin shidai Zhongguo tese

\footnotetext{
${ }^{1}$ We are grateful to the reviewers of the articles in this issue for their availability and insightful comments, which greatly helped to improve the quality of our research. We are also thankful to the journal's editor-inchief Guo Sujian for his personable approach and constructive feedback throughout the entire publication process. We also acknowledge the support of the Strategy AV21 research program of the Czech Academy of Sciences (http://www.avcr.cz/en/), which provided funding and a venue for the workshops. We are also thankful to Heike Holbig and Lutgard Lams who offered comments on the draft of this Introduction.
} 
shehuizhuyi sixiang $)^{2}$ and its subsequent inclusion within the party constitution. ${ }^{3}$ The new guiding ideology was also enshrined within the PRC's constitution at the first session of the 13th National People's Congress on 5-20 March 2018. ${ }^{4}$ Looking at these outcomes, we are inclined to envisage the lasting importance of ideology in the politics and the political system of the contemporary PRC. But even without falling into the temptation of making assumptions about the future, we should underline that, in many ways, our research anticipates some of the crucial questions that we believe will continue to be highly relevant for China and the world during Xi's second term as paramount leader.

Kerry Brown and Una Aleksandra Bērziņa-Čerenkova analyze in great detail the functioning of ideology as the CPC's guide to action. They conceptualize ideology as a body of practices, a system of beliefs, and its associated language, and they argue that its importance has not disappeared in the post-Mao era. This body of practices might appear to be more carefully concealed, but it still aims to achieve sustainable one-party rule, the assertion of discipline, and the control of the core tactical spaces. They identify a set of twelve keywords as fundamental tenets of the $\mathrm{CPC}$ in the first term of $\mathrm{Xi}$ Jinping's discursive space. These terms aim to achieve emotional as well as intellectual impact, and to assist in the delivery of the party's major goal for the twenty-first century - the creation of China as a great nation with the CPC at the heart of its governance. As expected, Xi Jinping Thought was enshrined in the party constitution at the 19th CPC Congress, with the limitation on the number of terms the State Chairman (guojia zhuxi) and State Vice-Chairman (guojia fuzhuxi) could serve being removed from the PRC's constitution by the National People's Congress in March 2018, ${ }^{5}$ effectively enabling Xi to rule for another decade. ${ }^{6}$ As the article states, Xi Jinping has until now been able to deliver focused political commitments, setting forward the practical goal of the "Great Rejuvenation of the Great Chinese Nation" and arguing that the party's rule is necessary for achieving it. Since the 19th CPC Congress, Xi Jinping's name has

\footnotetext{
${ }^{2}$ For more on Xi Thought, refer to, for instance, Lam, W.W. 2017. What is Xi Jinping thought? China Brief 17(12): 4-8. Retrieved from https://jamestown.org/program/what-is-xi-jinping-thought/ on 13 January 2018; and to Son, D. 2017. Xi Jinping thought vs. Deng Xiaoping theory. The Diplomat. 25 October. Retrieved from https://thediplomat.com/2017/10/xi-jinping-thought-vs-deng-xiaoping-theory/ on 15 February 2018. For more on ideology in the Xi era, refer, for instance, to [10,21].

${ }^{3}$ Xinhua. 2017. Xi Jinping: Secure a decisive victory in comprehensively building a moderately prosperous society, strive for the great victory of socialism with Chinese characteristics for a new era. Work report delivered to the 19th CPC national congress [Xi Jinping: juesheng quanmian jiancheng xiaokang shehui, duoqu xinshidai Zhongguo tese shehui zhuyi weida shengli. Zai Zhongguo gongchandang dishijiu quanguo daibiao dahuishangde baogao]. 27 October. Retrieved from http://news.xinhuanet.com/politics/19cpcnc/201710/27/c_1121867529.htm on 13 January 2018.

${ }^{4}$ National People's Congress. 2018. Zhonghua renmin gongheguo xianfa xiuzheng'an [Amendments to the PRC constitution]. March 12. Retrieved from http://www.npc.gov.cn/npc/xinwen/2018-03/12 /content 2046540.htm on 2 April 2018.

${ }^{5}$ Ibid.

${ }^{6}$ Another indication of Xi's growing power was provided by his elevation to the position of CPC "leadership core" (lingdao hexin) at the CPC Central Committee's Sixth Plenum on October 24-27, 2016. According to a People's Daily editorial, championing Xi Jinping as the "core" is in line with the "common wish of the entire party, the entire army, and the Chinese people of all ethnic groups" and is also in "the fundamental interest of the party and the nation" (People's Daily. 2018. Unswervingly promote comprehensive strict governance of the party. 27 October. Retrieved from http://opinion.people.com.cn/n1/2016/1027/c1003-28814106.html on 25 April 2018).
} 
become synonymous with the "New Era" in China, but his "Thought" is strictly associated with his signature traits analyzed in the article, such as strengthening the emotional appeal of the Party's message and asserting the continuity of China's rule by tapping into various, even contradictory, layers of Chinese cultural tradition.

Heike Holbig turns her attention to the crucial issue of economic growth and examines the legitimizing function of the widely debated concept of "New Normal" in China's public discourse from late 2013 to late 2016. Elaborating on existing studies of the economic implications of the phenomenon, she illustrates how political and intellectual elites have used this notion to frame the regime's economic performance in a manner conducive to the maintenance of its legitimacy. Although evidenced by rising living standards and material wealth, economic performance is an intangible phenomenon, experienced only through linguistic constructions and framings of social reality. The CPC's quest for legitimacy thus relies on shaping public perceptions and influencing the subjective meanings against which performance is measured. The article argues in favor of the importance of ideology in the reproduction of regime legitimacy and highlights the ideological processes of competition over the control of political language and the contestation and decontestation of political concepts in public discourse. Specifically, domestic economic performance, albeit slower than in the years of rapid growth, has been effectively mediated by perceptions that the Chinese party regime is outperforming other regimes. The author shows that the legitimizing function of the New Normal discourse results from targeting both international and domestic audiences at the same time. While addressing an international audience by focusing on the interaction between the Chinese and global economies and emphasizing the recognition China receives from the global community, the state media coverage of the New Normal examined by the article also targets the domestic audience. The legitimizing use of the concept as ascertained by Holbig appears again in $\mathrm{Xi}$ Jinping's Work Report to the 19th CPC Congress, which situates China's entry into the New Normal within the context of unprecedented domestic stability, progress, aspirations, determination, and achievements, all in stark contrast with the slow recovery of the international economy, multiple local conflicts, and the exacerbation of global issues.

Maurizio Marinelli critically engages with the debate on the Anthropocene and its interrelationship with the discourse on "eco-civilization" in the Xi Jinping era. In China, the term "eco-civilization" originally appeared in the academic domain in the 1980s, when the agricultural economist Ye Qianji (1909-2017) emphasized how humanity might benefit from nature, but also act in the nature's interests. Later, the term was appropriated by political discourse. Engaging in an analysis of the work of older generation intellectuals, Marinelli proves that the concept of eco-civilization, in a similar way to the Anthropocene, has a significant discursive power, with the potential to shift from the binary political economy discourses of "growth" versus "development", and "socialism" versus "capitalism", to generate eco-socially sustainable prosperity. Marinelli argues, however, that the way in which the idea of ecocivilization construction was enshrined in the CPC's constitution is a typical example of the "future perfect tense": projecting the construction of eco-civilization in a possible perfectible future. Especially in light of Xi Jinping's emphasis on "eco-civilization" in his opening speech at the 19th CPC Congress, the question today is whether or not Xi's 
poignant remark "Any harm we inflict on nature will eventually return to haunt us"7 (which would seem to echo Ye Qianji's 1980s position) stems from a sincere willingness to act, which could encourage the leadership to prioritize the need for harmony between humans and nature and implement relevant policies in the "new era" of the present, or whether it may prove to be mere political rhetoric. From the beginning of the 19th CPC Congress, the CPC incorporated "Beautiful China" into its two-stage development plan for building a great modern socialist country by the mid-twentyfirst century. Xi Jinping emphasized how China "must cherish our environment as we cherish our own lives", and then poignantly declared: "Taking a driving seat in international cooperation to respond to climate change, China has become an important participant, contributor, and torchbearer in the global endeavor for ecological civilization." 8 In China, the convergence of the academic discussion on ecocivilization with the politics-policy nexus could provide an opportunity to question the unsustainable logic that rapid industrialization, extensive land development, and full-scale urbanization leads to long-lasting progress.

Lutgard Lams offers another study of China's political discourse, targeting both domestic and foreign audiences. She examines the various strategies used by the Chinese authorities to disseminate the official narrative of China, also known as the "China Story", to international publics and as a means of legitimizing continued CPC rule at home. She argues that this discursive enterprise exemplifies the ongoing uneasy coexistence of transformative and conservative dimensions in the Chinese official discourse and communication climate. In the past two decades, although China's once monoglossic communication environment yielded a certain plurality of voices in debating nonsensitive political, social, and economic issues, the party-state continued to direct all participating voices and ensured their adherence to the "Main Melody" tuned by the CPC. Examining the convergences and divergences of the strategic narratives of Xi's era with the political discourse of previous leaderships, Lams finds that although new slogans, such as "the Chinese Dream", the "New Normal", the "Four Comprehensives" and the "Community of Common Destiny", appear to be Xi Jinping's hallmark and cumulatively contribute to the "Xi Jinping Thought", no paradigmatic change of ideology has emerged from these narratives. Yet, the $\mathrm{Xi}$ era has brought forth a significant intensification and diversification of the previous argumentation patterns and discursive strategies, which, in addition to domestic propaganda, have also had an impact on China's international communication and public diplomacy as the country has sought to adopt a more active role and promote its "China Model" as a newer and more equitable global order. At the 19th CPC Congress, Xi Jinping made clear that the party will continue to strengthen its "initiative in the ideological sphere" (yishixingtai lingyu zhudaoquan) and "discursive power" (huayuquan), while its "major country diplomacy with Chinese characteristics" (Zhongguo tese daguo waijiao) will seek to build a "new type of international relations" and a "human community of shared destiny" (renlei mingyun gongtongti).

\footnotetext{
${ }^{7}$ Xinhua 2017.

${ }^{8}$ Ibid.
} 
Finally, Ondřej Klimeš delves into the CPC's ideational governance in Xinjiang, where protracted ethno-political tensions have for decades jeopardized China's domestic security and foreign policy. The study focuses on how the party-state employs religion, culture, education, the media, and other intangible spheres as ideational apparatuses to instill desirable political values among Xinjiang's Uyghur community. The CPC continues to use ideology as a means of transforming the Uyghurs' worldview and political values into action, and regards it as a vital element of politics in Xinjiang. The study finds that the Xi leadership has adopted a novel security framing of the Xinjiang problem, brought forth by the region's pivotal position in China's foreign policy. To achieve "social stability and permanent order" and the "modernization of the Xinjiang governance system and capacity", during Xi Jinping's first term the national and provincial authorities advanced a complex "ethnic unity" and "de-extremization" policy. Its result is firstly the continued incorporation of the CPC's ideational objectives into new laws and regulations, which started with the latest escalation of violence after 2007. Secondly, its result has been a range of grassroots campaigns against allegedly "extremist" religious and cultural practices, including stepping up controls over the media, cyberspace, and other aspects of information transfer, political narrative, and public debate in Xinjiang. In line with practices illustrated by the other articles in this special issue, as well as existing research, this article concludes that the early $\mathrm{Xi}$ leadership substantially accelerated and expanded the development of mechanisms to control religion, culture, and other crucial attributes of Uyghur ethnic identity. Klimeš thus identifies no systemic departure in Xinjiang's ideational governance under Xi Jinping when compared with previous administrations, but rather an expansion and innovation of its techniques. The 19th CPC Congress hinted that, in future, the party was likely to continue the trends established in the ethnic, religious, and cultural policies associated with Xi's first term.

\section{Common Themes and Findings}

The aim behind this special issue is to offer a thematization and contextualization of propaganda, ideology, and political discourse in contemporary China, analyzing both their context and their internal developments, with a focus on the first term of $\mathrm{Xi}$ Jinping, but also in relation to previous eras by looking into their continuities and disjunctures. By thematization, we mean the exploration of the crucial thematic elements of propaganda, ideology, and political discourse in order to concentrate on key ideas, concepts, and subjects that deserve further reflection and in-depth analysis, such as one-party rule, the public discourse on "the New Normal", the intellectual and political discourse on "ecological civilization", the prospective "community of common destiny", and "ethnic unity and de-extremization" in Xinjiang. Our decision to use thematization as a guideline is not intended to be all-encompassing since while we have identified these themes as strategically important and recurrent in the political discourse, they are by no means the only ones. The selected thematic elements, however, appear to be among the most relevant, as they relate to a multitude of cultural-political and socio-economic domains. Therefore, we believe that they allow us to shed light on the multiple layers of the politics-policy nexus (the connection of political goals with policy tools). Our study indicates that these thematic elements are often used as 
propagandist rhetorical tropes, and that it is necessary to delve deeply into the origins, the development, and the context of the relevant political and/or intellectual debates in order to understand the distinctive value and quality of the selected themes. Therefore, thematization becomes a method of analysis, a systematic way to conduct a critical inquiry, which goes beyond the headlines and offers insights into the selected themes of propaganda, ideology, and political discourse, thus proving their relevance even beyond the 19th CPC Congress.

Thanks to our thematization approach, we have identified a number of common themes, which we believe are of key significance for socio-political research in contemporary Chinese politics. The Xi era has brought forth further elaborations on guiding ideological concepts (common themes for Brown and Bērziña-Čerenkova), inventive ideational framings by the leadership of phenomena usually perceived as tangible (Holbig), complex interplays of political discourse and intellectual debates on crucial topics, such as "eco-civilization", related to the social and environmental challenges for China's present and future development (Marinelli), intensified and diversified argumentation patterns and discursive strategies (Lams), and, in particular contexts, consolidated ideational governance over individual values, beliefs, and loyalties (Klimeš). The authors find, however, that the general trends of the Xi era do not present paradigmatic shifts, but rather an overall reassertion-cum-innovation of previous uses of ideology, propaganda, and political discourse in the Maoist and post-Maoist eras. This collection of articles thus corroborates the argument that the innovation of governance terminology under Xi does not necessarily mean a revision of basic patterns and techniques of governance ([14], 322).

Furthermore, two of our authors (Holbig and Lams) notice an increasingly inseparable conjunction of domestic and international propaganda into a single discursive process. As a result of global information era trends, it is often no longer possible to differentiate clearly between the CPC's internal (duinei) and external propaganda (duiwai xuanchuan). The other articles (Brown and Bērziña-Čerenkova, Marinelli, and Klimeš) also indicate that under the Xi leadership, even seemingly exclusively domestic ideational and discursive issues can have international implications and are, therefore, approached with closer regard to China's position in global affairs. This is caused, firstly, by the information globalization of the internet age and, secondly, by the fact that Xi's China has developed a more assertive international strategy, manifested by the aspirations of its "major country diplomacy with Chinese characteristics" (Zhongguo tese daguo waijiao) to forge "a new type of international relations" (xinxing guoji guanxi), ${ }^{9}$ or even to be the "guide" (yindaozhe) in building a "new international order" (guoji xinzhixu). ${ }^{10}$

The authors also note the continuous appearance of the compound word wenming in political discourse. Here, the authors analyze different, as well as complementary, angles, such as the attention paid by the leadership to the concept of "spiritual civilization" (Brown and Bērzina-Čerenkova), the problematic debate on the civilizational state vis-à-vis the complexity of translating "ecological civilization" - often

\footnotetext{
${ }^{9}$ National People's Congress 2018.

${ }^{10}$ China Cadre Learning Network. 2017. The "two guidances" raised for the first time by Xi Jinping deeply meaningful [Xi Jinping shouti "liangge yindao" you shenyi]. Retrieved from http://www.ccln.gov. cn/hotnews/230779.shtml on 13 January 2018.
} 
presented in the official English texts as "progress" (Marinelli), and the state-driven reshaping of personal religious and cultural values in the name of "civility" in the case of the Uyghurs in Xinjiang (Klimeš). The relevance of the wenming concepts in the official political discourse is analogous and closely related to the tighter weaving of China's cultural and philosophical traditions into the contemporary ideology and propaganda of the Chinese party-state. This process is observable both in external national image and soft power building efforts (Lams) and in domestic ideational governance (Klimeš). ${ }^{11}$ Finally, all authors find that official ideology, propaganda, and political discourse is designed by the CPC to describe in the "future perfect tense" (Marinelli) the political goals and the image of an ideal, "pretend world" of the future (Klimeš; [13], 346), rather than current reality.

Altogether, these conclusions also open up the space for further research, for example on the multiplying ways in which the official ideology is transferred by political discourse and propaganda onto various PRC constituencies; on the interplay of these transfer processes among the various political actors both within and without the CPC; on the impact of official ideology on society and individuals; and on the reactions of target groups to the party-state's ideational efforts.

This special issue thus illustrates in multiple ways the strong aspiration of the contemporary Chinese party-state to employ propaganda and political discourse in order to project ideology when dealing with both domestic society and the international community. At the pivotal 19th CPC Congress in October 2017, Xi Jinping heralded the beginning of a "new era". The question remains, however, as to whether under the CPC's leadership there is any possibility in contemporary China of achieving a truly "new era" in the use and function of official ideology, propaganda, and political discourse, or whether we will witness a continuous reassertion-cum-innovation of this fundamental triad which, while offering newly coined keywords, will substantially aim at strengthening one-party rule.

Open Access This article is distributed under the terms of the Creative Commons Attribution 4.0 International License (http://creativecommons.org/licenses/by/4.0/), which permits unrestricted use, distribution, and reproduction in any medium, provided you give appropriate credit to the original author(s) and the source, provide a link to the Creative Commons license, and indicate if changes were made.

\section{References}

1. Brady, M.A. 2012. China's thought management. Abingdon: Routledge.

2. Brown, K. 2012. The communist party of China and ideology. China: An International Journal 10 (2): $52-68$.

\footnotetext{
${ }^{11}$ For more on the CPC's politically motivated reinvention of China's tradition, see e.g. Yang, Z. 2017. Xi Jinping and China's traditionalist restoration. China Brief 17(9): 8-13. Retrieved from https://jamestown. org/program/xi-jinping-chinas-traditionalist-restoration/ on 15 February 2017; Minzner, Carl. 2014. Old wine in an ancient bottle: Changes in Chinese state ideology. China Brief 14(6): 13-16. Retrieved from https://jamestown.org/program/old-wine-in-an-ancient-bottle-changes-in-chinese-state-ideology/ on 15 February 2018; or Perry, E. J. 2013. Cultural governance in contemporary China: "Re-orienting" party propaganda. Harvard-Yenching Institute Working Paper Series. 17 May. Retrieved from http://www. harvard-yenching.org/features/hyi-working-paper-series-elizabeth-perry on 2 April 2018.
} 
3. Cao, Q., H. Tian, and P. Chilton, eds. 2014. Discourse, politics and media in contemporary China. Amsterdam: John Benjamins.

4. Dickson, B.J. 2016. The dictator's dilemma: the Chinese communist party's strategy for survival. New York: Oxford University Press.

5. Edney, Kingsley. 2014. The globalization of Chinese propaganda: International power and domestic political cohesion. New York: Palgrave Macmillan.

6. Gilley, B. 2011. Paradigms of Chinese politics: Kicking society back out. Journal of Contemporary China 20 (70): 517-533.

7. Heath, T. 2014. China's new governing party paradigm: Political renewal and the pursuit of national rejuvenation. Farnham: Ashgate.

8. Holbig, H. 2013. Ideology after the end of ideology: China and the quest for autocratic legitimation. Democratization 20 (1): 61-81.

9. Johnson, C., ed. 1973. Ideology and politics in contemporary China. Seattle: University of Washington Press.

10. Lam, W.W. 2015. Chinese politics in the era of Xi Jinping: Renaissance, reform, or retrogression? New York: Routledge.

11. Lampton, D.M. 2014. Following the leader: Ruling China, from Deng Xiaoping to Xi Jinping. Berkeley: University of California Press.

12. Li, C. 2016. Chinese politics in the Xi Jinping era: Reassessing collective leadership. Washington, D.C.: The Brookings Institution.

13. Link, P. 2013. An anatomy of Chinese: Rhythm, metaphor, politics. Cambridge: Harvard University Press.

14. Noesselt, N. 2017. Introduction: "New normal" under xi Jinping. Journal of Chinese Political Science 22 (3): 321-325.

15. Pieke, F.N. 2009. The good communist: Elite training and state building in today's China. Cambridge: Cambridge University Press.

16. Schoenhals, M. 1992. Doing things with words in Chinese politics. Berkeley: University of California Press.

17. Schurmann, F. 1968. Ideology and organization in communist China. Berkeley and London: University of California Press and Cambridge University Press.

18. Schwartz, B.I. 1970. Communism and China: Ideology in flux. New York: Atheneum.

19. Shambaugh, D. 2008. China's communist party: Atrophy and adaptation. Washington D.C. and Berkeley: Woodrow Wilson Center Press and University of California Press.

20. Wright, T. 2015. Party and state in post-Mao China. Cambridge: Polity Press.

21. Zhao, S. 2016. Xi Jinping’s Maoist revival. Journal of Democracy 27 (3): 83-97.

Dr Ondřej Klimeš is a researcher at the Oriental Institute of the Czech Academy of Sciences. His research interests include the Uyghur national movement, the politics of contemporary Xinjiang, and the ideology and propaganda of contemporary China. He is the author of the monograph Struggle by the Pen: the Uyghur Discourse of Nation and National Interest, c. 1900-1949 (Brill, 2015). His other research has been published in the Central Asian Survey or by the Europe China Research and Advice Network (ECRAN). Contact: klimes@orient.cas.cz

Dr Maurizio Marinelli is a Senior Lecturer (Associate Professor) in East Asian History at the University of Sussex. The focus of his research is located at the crossroads of Chinese history, politics and society. Through this interdisciplinary lens, the exploration of political, cultural and socio-spatial transformation in China becomes a means by which to engage with larger related universally experienced themes, such as: the connections between colonial and global cities, citizenship construction, and the Chinese political and intellectual debates on public value, prosperity and ecological civilisation. His research has been published in various journals, including Theory and Society, China Information, Cultural Studies Review, Journal of Chinese Current Affairs, Postcolonial Studies, Urban History. Contact: m.marinelli@sussex.ac.uk 